The molecular relationship between the breakdown of hæmoglobin and the production of carbon monoxide that would be expected from this hypothesis can, in fact, be demonstrated experimentally. The amount of carbon monoxide exhaled per day by a subject was calculated from repeated determinations of the concentration of carbon monoxide in the expired air during several days, and from the average respiratory volume. This came to $6.8 \mathrm{mgm}$. carbon monoxide per day, while an approximate estimation of the amount of hæmoglobin broken down in one day (calculated from the total hæmoglobin and an average life-span of the erythrocytes of 120 days) was $4 \mathrm{gm}$. The relation between these values is 1:590, while the relation between the molecular weights of carbon monoxide and of hæmoglobin is $1: 600$, if the latter is calculated for each hæmin group.

The endogenous formation of carbon monoxide and its relation with hæmolysis and internal hæmorrhage ${ }^{4}$ may be explained on the assumption that carbon monoxide is liberated in connexion with the intra vital breakdown of hæmoglobin.

A detailed account of these investigations will be published in Acta physiologica Scandinavica.

Laboratory of Clinical Physiology, TORGNY SJöSTRAND

Karolinska Sjukhuset, Stockholm.

' Sjöstrand, T., Nature [168, 729 (1951)].

- Lemberg, R., Legge, J. W., and Lockwood, W. H., Biochem. J., 33 $754(1939) ; 35,339$ (1941).

'Lemberg, R., Biochem. J., 29, 1322 (1935).

- Sjostrand, T., Scand. J. Clin. Lab. Invest., 1, 201 (1949).

\section{Enzymatic Conversion of the Stereoisomers of isoLeucine to the Corresponding $\alpha$-Keto-Acids}

THE optical isomers of $\alpha$-keto- $\beta$-methylvaleric acid have been prepared by enzymatic oxidation of the corresponding D-amino-acids ${ }^{1}$. The keto-acid isomers (and their 2,4-dinitrophenylhydrazones) prepared by enzymatic oxidation of $\mathrm{D}$-isoleucine and D-alloisoleucine exhibited optical rotations which were equal in magnitude and opposite in direction ${ }^{1,2}$. Furthermore, from microbiological studies (to be reported in detail elsewhere), a purity of at least 98 per cent may be assigned to the lævorotatory isomer of $\alpha$-keto- $\beta$-methylvaleric acid prepared by enzymatic oxidation of $\mathrm{D}$-isoleucine. These findings indicate that the configuration about the $\beta$-carbon atom is not measurably altered by enzymatic oxida. tion of the $\mathrm{D}$-amino-acids or during isolation of the keto-acid.

It has now been found that oxidation of the $\mathbf{L}$-isomers of $i$ soleucine and alloisoleucine by L-aminoacid oxidase of snake venom, or transamination between these amino-acid isomers and $\alpha$-ketoglutaric acid catalysed by a soluble hog's heart preparation, leads to similar results, that is, formation of optically active keto-acid isomers which have been isolated as the 2,4-dinitrophenylhydrazones. The experiments with snake venom oxidase were carried out essentially as described for those with D-amino-acid oxidase, except that crystalline beef liver catalase was added to prevent further oxidation of the keto-acids. In the transamination reactions, which did not go to completion, the $\alpha$-keto- $\beta$-methylvaleric acid formed and the residual $\alpha$-ketoglutaric acid were precipitated by addition of 2,4-dinitrophenylhydrazine. The hydra-
ENZYMATIC FORMATION OF a-KETO- $\beta$-METHYLVALERIC ACIDS FROM FOUR ISOMERS OF isoLeUcINe

\begin{tabular}{|c|c|c|}
\hline Substrate & Enzyme & $\begin{array}{c}{[a] D^{26} \text { of resulting }} \\
\text { keto-acid hydra- } \\
\text { zone }\end{array}$ \\
\hline $\begin{array}{l}\text { D-isoLeucine } \\
\text { L-isoLeucine } \\
\text { L-isoLeucine }+ \\
a-k e t o g l u t a r a t e \\
\text { D-alloisoLeucine } \\
\text { L-alloisoLeucine } \\
\text { L-alloisoLeucine }+ \\
a \text {-ketoglutarate }\end{array}$ & $\begin{array}{l}\text { D-Amino-acld oxidase } \\
\text { I-Amino-acid oxidase } \\
\text { Transaminase } \$ \\
\text { D-Amino-acid oxidase } \\
\text { L-Amino-acid oxidase } \\
\text { Transaminase }\end{array}$ & $\begin{array}{l}-16.7^{\circ} \\
+17 \cdot 3^{\circ} \\
+16.7^{\circ} \\
+16 \cdot 7^{\circ} \\
-17.1^{\circ} \\
-16.4^{\circ}\end{array}$ \\
\hline
\end{tabular}

* Specific rotation of the 2,4-dinitrophenylhydrazone of a-keto- $\beta$. methylvaleric acid ( 2 per cent solution in ethanol : $2 \mathrm{dm}$. tube). Hog's kidney acetone powder extract.

$\$$ Crotalus adamanteus venom.

zones of $\alpha$-keto- $\beta$-methylvaleric acid and $\alpha$-ketoglutaric acid were separated by counter-current distribution using ethyl acetate and aqueous sodium carbonate as the solvents. The hydrazones were recrystallized from water, dried, and characterized by nitrogen analysis and melting point. The specific optical rotations of the 2,4-dinitrophenylhydrazones of $\alpha$-keto- $\beta$-methylvaleric acids formed by enzymatic action from the four isomers of isoleucine are given in the accompanying table; within experimental error, the values are in good agreement.

These results demonstrate that the optical configuration about the $\beta$-carbon atom of the four isomers of isoleucine is maintained during enzymatic oxidation and transamination, and that a reversible $\alpha$ - $\beta$-unsaturation leading to loss of asymmetry at the $\beta$-carbon does not occur. However, the possibility is not excluded that reversible $\alpha-\beta$-unsaturation may be enzymatically directed so as to preserve the configuration of the $\beta$-carbon atom.

National Cancer Institute, National Institutes of Health, Bethesda, Maryland. July 11.

1 Meister, A., J. Biol. Chem., 190, 269 (1951). Greenstein, J. P., Levintow, I.., Baker, C. G., and White, J., J. Biol.
Chem., 188, 647 (1950).

\section{Transmission of Natural and Synthetic Mica in the Ultra-Violet}

THE various minerals belonging to the mica group are all characterized by the ease with which they cleave. The reason for this behaviour is found in their structure, which consists in all cases of a double sheet of linked silicon-oxygen tetrahedra of the hexagonal type $\left(\mathrm{Si}_{4} \mathrm{O}_{10}\right)^{1}$. One in every four silicon ions is replaced by aluminium in most of the natural occurring micas (phlogopite, muscovite, biotite), thus giving the basic $\mathrm{AlSi}_{3} \mathrm{O}_{10}$ units; these are firmly bound by the incorporation of aluminium, magnesium and iron ions and hydroxyl groups. The double sheets are weakly linked by potassium ions, and it is along this plane that cleavage takes place. The most important micas conform to the idealized formulæ:
Muscovite
$\mathrm{KAl}_{2}\left(\mathrm{AlSi}_{3} \mathrm{O}_{10}\right)(\mathrm{OH})_{2}$
Phlogopite $\mathrm{KMg}_{3}\left(\mathrm{AlSi}_{3} \mathrm{O}_{10}\right)(\mathrm{OH})_{2}$,

but a multitude of substitutions can take place ; for example, the magnesium can to some extent be replaced by iron, which gives biotite:

$$
\mathrm{K}(\mathrm{MgFe})_{3}\left(\mathrm{AlSi}_{3} \mathrm{O}_{10}\right)(\mathrm{OH})_{2} \text {. }
$$

Attempts to synthetize mica were first made more than fifty years ago, but it has been difficult to grow 